\title{
IMPROVING WRONGFUL CONVICTION REVIEW: LESSONS FROM A COMPARATIVE ANALYSIS of Continental Criminal Procedure
}

\author{
Paul J. Saguil.
}

The situdy of wrongful conviction has yiclded much evidence oulining that factors such as mistaken identification. false confessions, unsavoury informamts, and misconduct on the part of the prosecution, defence, and police, inter alia, are causes of wrong ful conviction common to most, if not all, criminal justice systems. Despite the resurgence of scholarly and popular interest in the phenomenon of urongful conviction, there are a number of gaps in our knowledge and there is little scholarship available that addresses the subject of this article.

In this article. the author addresses the question posed by Professor and Dean of Social Ecology. (University of Califormia - Inine) C. Ronald Ihul: "Are some criminal justice systems more likely. 10 produce urongful convictions than others?" The author undertakes a comparative siuch of criminal procedure in France and Germany in order to critique and appraise the Canadian approach to wrongful conviction review. Ile argues that incorporating specific elements of Continental practice into our domestic procedures nould substantially increase and improve the opporfunities for correcting miscarriages of justice in Canada.
L.'̈lude de la condommation injusifice a amplement promive quic des factaurs comme lerreur sur la persomme, les fonsse's confessions. les informateurs douteur et l'incondinife de la part du poursuivam, de la defense et de la police, entre autres choses, somt des conuses de condommation injustifice qui existent dans la phupart, sinon tous les systèmes de justice pénate. Malgre la résungence de l'intert scientifique et populaire pour le phinomine des condamnations injusfifies, it y a tout de mime des lacunes dans nos comnaissances of il $y$ a peu de connaissances disponibles abordan f objet de cet arficle.

Dans cef article. I'anfeur aborde la question posice par le professem ef doyen en cologic sociale (Universife de la (alifornie - Inine). C. Ronold HIJf. à sav'oir : "Fst-ce que cerlains systimes de justice pénale som davanage portes aux condamnations injustifiées que d'autres? L Louteur a fait une itude comparative des procédures pénales en France er en Allemagne dans le but de critiquer et d'evaluer lapproche canodienno à litude des condammations injustifieve. II prifend que le fait dinchure des climems spécificues de la pratique curopienne dans nos procédurex notionale augmenterait ef amiliorerail considirablement les passibilités de corriger les erreurs judiciaires au Canada.

\section{TABLE OF CONTENTS}

I. INTRODUCTION ............................... 118

II. AdVERSARIAL AND NON-ADVERSARIAL SYSTIEMS $\ldots \ldots \ldots \ldots \ldots 120$

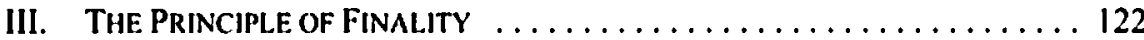

IV. APPELL.ATE AND POST-APPELLLATE REVIEW $\ldots \ldots \ldots \ldots \ldots \ldots \ldots 123$

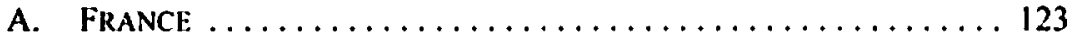

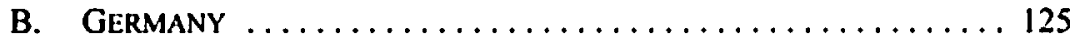

V. REMEdYing WRONGFUL CONVICTIONS IN CANADA $\ldots \ldots \ldots \ldots \ldots 127$

A. THE Minister's ROLE $\ldots \ldots \ldots \ldots \ldots \ldots \ldots \ldots \ldots \ldots \ldots \ldots$

B. THE ROLE OF THE COURTS . . . . . . . . . . . . . . . . 129

B.A. (Hons.), York University; LL.B., Osgooxle Hall Law School, York Universily. The author gratefully acknowledges the guidance and mentorship of Professors Alan Young and Chris Sherrin, the (then) co-directors of the Innocence Project clinical program at Osgoode Hall Law School. The author also wishes to commend all past and present students involved in the work of the Project. particularly his colleagues from the 2005-2006 academic year. This article is dedicated to victims of miscarriages of justice who are still secking a remedy. 


\section{IMPROVING WRONGFUL CONVICTION REVILW - LESSONS}

of Comparative Procedure $\ldots \ldots \ldots \ldots \ldots \ldots \ldots \ldots \ldots \ldots \ldots$

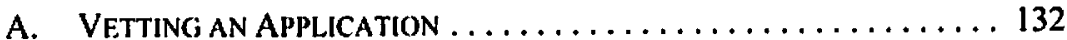

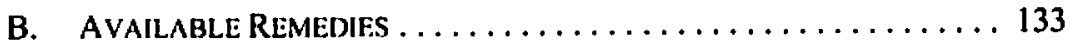

C. Determining When a Remedy is Justified . . . . . . . . . 134

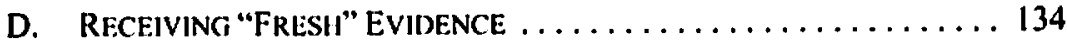

VII. Conclusion: The Plia for Util.izing Foreign Experience . . . . . . 135

\section{INTRODUCTION}

When [the adversarial system] works well, it is probably unrivaled at getting at the truth. When it works badly, the risk of wronglul conviction is probably greater than under the alternative inquisitorial system which operates in most of Continental Europe.

- G. Waller, Chair of the British Section of the Intemational Commission of Jurists'

The Association in Defence of the Wrongly Convicted lists over two dozen Canadian cases of wrongful convictions, although there are indications that this number may be a conservative account. ${ }^{2}$ Indeed, like in the United States, ${ }^{3}$ it is difficult to accurately estimate the extent to which wrongful convictions occur in Canada since there is no systematic data kept of such statistics. ${ }^{+}$This is only to reiterate that the phenomenon of wrongful conviction is a serious problem, despite the difficulty of measuring its magnitude or frequency. Cases like Guy Paul Morin, David Milgaard, and Thomas Sophanow have clearly raised public awareness and academic concern in Canada about this issue in recent years, especially in light of the high-profile commissions and inquiries that have been appointed to investigate the phenomenon." That over 500 people attended the 2005 "Unlocking Innocence" Conference in Winnipeg to discuss a number of issues that contribute to wrongful conviction

$1 \quad$ U.K.. Justice. Mfiscarriages of Justice (Cumbridge: E. \& E. Plumridge, 1989) at 23.

2 Association in Defience of the Wrongly Convieted (AIDWYC). "Cases" and "Past Cases," online: AIDWYC <http://www.aidwyc.org>.

3 C. Ronald Huff, "Wronglul Convictions: The American Experience" (2004) 46 Canadian Joumal of Criminology and Criminal Justice 107 at 109.

- Although the Department of Justice (Canada) has published annual repons since 2003 about its conviction review process, these statistics can in no way be regarded as (nor do they purport to be) definitive or exhaustive. These annual reports can be accessed on the Department of Justice website, online: Department of Juslice Canada <hitp:/www.justice.ge.ca/en/ps/cer/index.html>.

Sec e.g. Canada, Government of Newfoundland and Labrador, The Lamer Commission of Inquiry Pertaining to the Cases of: Ronald Dalton. Gregory Parsons, Randy Druken - Report and Ammexes (St. John's: Depurtment of Justice. 2006), online: Govemment of Newfoundland and Labrador <http://www.justice.gov.nl.ca/just/lamer>; Canada, Govemment of Saskatchewan, Commission of Inquiry Into the Wrongful Conviction of David Mllgard, online: Milgaard Inquiry <http:/f www.milgaardinquiry.ea> [Milgard Inquiry]: Canada, Government of Manitoba, Commiksion of Inquiry Into Cerlain Aspects of he Trial and Conviction of James Driskell (Winnipeg: Manitoba Justice, 2007), onlins: <http:/www.driskellinquiry.ca>. On 28 August 2007, the Ontario Court of Appeal set aside the conviction of Steven Truscott: R. v. Truscon, 2007 ONCA 575. For more related documents sec: AIDWYC, "Library - AIDWYC - Skeven Truscott," online, AIDWYC <http:// aidwye.org/library.c $\mathrm{fm}>$. Please note that this article was written before the Truscolt appeal was heard and thus does not take into account any aspect of the Court of Appeal's decision. 
indicates the serious interest in Canada and across the world in addressing the problem." Indeed, the organizers of the event boasted that the event was truly "international in scope and attendance."

However, one of the key topics that was missing from the conference agenda was a discussion of whether there could be anything learned from other jurisdictions in the quest to remedy miscarriages of justice. The study of wrongful conviction has yielded much evidence that demonstrates that factors such as mistaken identification, false confessions, unsavoury informants, and misconduct or negligence on the part of the prosecution, defence, and police, inter alia, are causes of wrongful conviction common to most, if not all, criminal justice systems. However, although there have been many comparative criminal procedure studies done between common law jurisdictions like Canada, the United States, the United Kingdom, Australia, and Scotland, and indeed, even between common law and civil law jurisdictions such as France and Germany, there is little scholarship available that addresses the subject of this article. As noted by Richard Leo, "[d]espite the resurgence of scholarly and popular interest in the phenomenon of wrongful conviction, there are a number of gaps in our knowledge and problems - methodological, conceptual, and theoretical - in our understanding of miscarriages of justice." If criminologists and legal scholars wish to develop theories about the study of wrongful conviction, they need to move beyond the legal categories and concepts handed to them by journalists and lawyers and they need to do more than descriptive case studies that re-circulate the same essential ideas."

This article touches upon one of the research questions proposed by C. Ronald Huff: "Are some criminal justice systems more likely to produce wrongful convictions than others?"10 This will involve a survey of post-conviction reviews in other jurisdictions in order to find out whether there is anything in the way that a particular system addresses complaints of wrongful conviction that helps explain the existence of miscarriages of justice within that system. Although empirical correlation data for such a hypothesis does not exist" - indeed, probably cannot exist - this article demonstrates that particular systemic goals and ideals should be taken into account when dealing with miscarriages of justice. As Leo argues, "scholars need to seek out root causes, not legal causes, of wrongful conviction ... if criminologists [and legal scholars] wish to develop theories, frameworks, or paradigms for better understanding the general patterns, logics, and characteristics of wrongful conviction cases." 12 This article compares compares the Canadian approach of ministerial review to the procedures conducted in European jurisdictions, ${ }^{3}$ namely France and Germany. Ultimately,

Unlocking Innocence: An Intemational Conference on Avoiding Wrongful Convictions, Winnipeg. Manitoba (20-22 October 2005), online: Unlocking Innocence <http://www.wrongfulconviction.ca>. lbid.

$8 \quad$ Richard $A$. Leo, "Rethinking the Study of Miscarriages of Justice: Developing a Criminology of Wrongful Conviction" (2005) 21 Joumal of Contemporary Criminal Justice $20 \mathrm{I}$ at 212.

lbid. at 215 .

10 C. Ronald Huff, "What Can We Learn from Other Nations about the Problem of Wronglul Conviction?"” (2002) 86 Judicature 91 al 97.

1 See generally Gordon C. Barclay. "The Comparability of Data on Convictions and Sanctions: Are International Comparisons Possible?"'(2000) 8 Luropean Journal on Criminal Policy and Research 13. Leo, supra note 8 a 213.

The in formation about non-English-speaking jurisdictions is necessarily second-hand, although great care has been taken to canvass as many resources as possiblet to achieve a clear understanding of forcign systems. 
by engaging in a critical comparative analysis, we will be better able to understand the unique characteristics of our own legal system, for "[w]hen one is immersed in his own law, in his own country, unable to see things from without, he has a psychologically unavoidable tendency to consider as natural, as necessary ... things which are simply due to historical accident or temporary social situation." 14

\section{ADVERSARIAL. AND Non-AdVERSARIAL SYSTEMS}

It is necessary to first discuss the concepts of adversarial and non-adversarial systems and the different elements of criminal procedure to contextualize the observations about the Canadian and Continental legal systems. There are distinct differences between the criminal procedures of Canada, France, and Germany, and these necessarily affect any wrongful conviction review mechanisms that may be adopted within these systems. It must be recognized that "[a] system of criminal justice is strongly related to its underlying historical, social and political environment, as well as the structure of authority on which it is based. [Although] too many historical, social, political, and cultural questions are involved to give a comprehensive and satisfying account," is it is, however, necessary to have some basic understanding of the workings of the criminal justice system before engaging in critiques over the various review mechanisms that are utilized among the different jurisdictions.

The Supreme Court of Canada has stated that "it is well recognized that the adversarial process is an important part of our judicial system and an accepted tool in our search for the truth."16 In the "narrow sense," the adversarial system is "a method of adjudication characterized by three things: an impartial tribunal of defined jurisdiction, formal procedural rules, and ... assignment to the parties of the responsibility to present their own cases and challenge their opponents." "In the context of criminal proceedings and for the purposes of this discussion, the essential distinctions are the extent of judicial involvement or supervision in the investigation and prosecution/trial stages (the ideal of the adversarial system is that judges are disinterested arbiters rather than engaged supervisors) and the way in which evidence is received by the court. In Canada, the police are responsible for gathering evidence and either they or the prosecutor will lay charges; prosecutors are responsible for the preparation of a case after a charge has been laid. The judge does not assist the parties in calling witnesses and presenting their own evidence. The admissibility and exclusion of evidence is governed by statutory provisions and the common law, and is subject to constitutional standards.

Criminal procedure and investigation in European countries operates in a very different manner. In contrast to the adversarial approach, which takes it shape from a contest or a

Pierre Lepaulle, "The Function of Comparative Law with a Critique of Sociological Jurisprudence" (1922) 35 Harv. L. Rev. 838 at 858.

13 Thomas Volkmant1-Schluck, "Continental European Criminal Procedures: True or Illusive Medel?" (1981) 9 Am. J. Crim. L. I al 3-4: sec also Mirjan Damaska, "Structures of Authority and Comparative Criminal Procedure" (1975) 84 Yale L.J. 480.

is R. v. Cook, [1997] I S.C.R. I113 at para. 21 [emphasis in original].

1" David Luban, Lowyers and Justice: An Ethical Study (Princeton: Princeton University Press, 1998) at 56-57. 
dispute, it has been suggested that adjudication in the civil law tradition is structured as an official inquiry. ${ }^{18}$ Non-adversarial criminal procedure has been described in this manner:

In a civil-law system ... the trial culminates an official inquiry whose object is to determine whether the defendant is guilty and, if so, what sanction to imposc. The court is responsible for presenting the proofs and is not bound by the parties' positions when it formulates the issues and reaches an ultimate decision. Trial procedures in this nonadversary model are simpler. less Icchnical. and less lawyer dominatcd than in the adversary model. ${ }^{19}$

Courts in Germany are not bound by rules of evidence; similarly, a free evaluation of evidence is conducted in the French system. ${ }^{20}$ The inquisitorial or non-adversarial approach is largely predicated upon the idea that an intensive screening process secures the adjudication of only factually guilty defendants: procedural rules are deemed far less important than accurate determinations of fact. ${ }^{21}$ The Continental process can be best understood as a continuous progression from investigation to trial and sentencing. This is, admittedly, a broad generalization and does not account for the nuances and technicalities found within individual systems in Europe. Moreover, there is some evidence that the boundaries between "adversarial" and "non-adversarial" systems have been blurred by recent developments; the hard dichotomy between adversarial and non-adversarial styles of adjudication appears somewhat stilted when the actual practices of different jurisdictions are taken into consideration. ${ }^{22}$

Nevertheless, different approaches to investigation, evidence hearing, and adjudication will necessitate varying standards and procedures of review at the appellate and postappellate level. Although the role of appellate judges in both systems is similar in that appellate review in both systems is based on a written record. appellate review is more circumscribed in an adversary system given the reluctance to interfere with findings of fact of the court of first instance, with jury verdicts, and with the exercise of a trial judge's discretion. In Canada, a defendant appealing against conviction on a question of fact must obtain the leave of the court of appeal or obtain a certification from the trial judge; further, prosecutors can only appeal questions of law. ${ }^{23}$ In contrast, prosecutors and convicted defendants in Germany and France have the right to appeal issues about the law and, in certain circumstances, questions of fact. ${ }^{24}$

I* Erik Luna, "A Place for Comparative Criminal Procedure" (2004) 42 Brandeis L.J. 277 at 295.

19 Edward A. Tomlinson, "Nonadversarial Justice: The French Experience” (1983) 42 Md. L. Rev. 131 at 134.

21 Nigel Osner, Anne Quinn \& Giles Crown. eds., The Royal Commission on Criminal Justice: Criminal Jusfice Systems in Other Jurisdictions (London: HMSO, 1993) at 83, 93.

$21 \quad$ Luna, supra note 18 at 297.

:2 Ibid. 298; see also Jörg-Martin Jehle, "Prosecution in Europe: Varying Structures, Convergent Trends" (2000) 8 European Joumal on Criminal Policy and Research 27.

3 See Criminal Code, R.S.C. 1985, c. C-46, ss. 675(1), 676(1) [Criminal Code].

$\therefore$ Osner, Quinn \& Crown, stupra note 20 at 90. 


\section{The Principle of Finality}

This leads to another important consideration in conceptualizing the different forms of post-conviction review: the principle of finality. Finality is a judicially-developed principle that brings criminal proceedings to an end once the matter is decided "according to law." In other words, the judgment is considered as conclusive against all persons regarding the legal results or state of affairs which it actually affects. On one hand, public tranquility and the common good require that every case should end at some point and that when a matter has finally been disposed of, it should no longer be relitigated. If finality were absent from the criminal process, this would frustrate both the deterrent function of law and the effectiveness of rehabilitation. ${ }^{26}$ However, a lack of concern with error is also historically characteristic of westem criminal legal systems as throughout western legal history there has been a strong disinclination to recognize the possibility of error in criminal judgments. ${ }^{27}$ Finality has thus operated as a significant bar or hindrance to the exercise of appeal rights; it has been used as justification to restrict appellate courts from engaging in expansive reviews of trial-level factual findings. Understanding curial deference and the premium placed on stability and order in the Canadian and Continental legal systems can help further contextualize the post-conviction review process.

A famous articulation of the judiciary's aversion to re-hearings of questions of fact in the common law context is found in Lord Denning's judgment dismissing the civil action of the Birmingham Six: "If the six men win, it will mean that ... the Home Secretary would either have to recommend that they be pardoned or he would have to remit the case to the Court of Appeal. That would be such an appalling vista that every sensible person in the land would say: it cannot be right that these actions should go any further. ${ }^{28}$ The centrality of the principle of finality has also been affirmed in the Canadian legal system. Justice Charron (as she then was), writing for the Ontario Court of Appeal in R. v. H.(E. $)^{29}$ and dismissing the applicants' requests to reopen their appeal, reasoned that "the appellate process cannot become or even appear to become a never-closing revolving door through which appellants come and go whenever they propose to argue a new ground of appeal." ${ }^{30}$ Similarly, L'Heureux-Dubé J., in a concurring judgment in $R$. v. Sarson, ${ }^{31}$ wrote: "Finality in criminal proceedings is of the utmost importance." ${ }^{.32}$

Finality operates in a slightly different way in France and Germany not only because of the different rules of criminal procedure but also because of the civil law system in which finality is "built into the system" because the grounds for review and the appellate powers

3 Gary T. Trotter, "Justice, Politics, and the Royal Prerogative of Mercy: Examining the Self-Defence Review" (2001) 26 Queen's L.J. 339 at 359. Carlson Anyangwe, "Finality and Miscarriage of Justice in Criminal Law: Post-Conviction Remedies in Common and Civil Law Jurisdictions" (1998) 30 Zambia L.J. 51 at 53-54. Rnger Berkowity, "Error-Centricity, Habeas Corpus and The Rule of Law as The Law of Rulings" (2004) 64 La. L. Rev. 477 at 484-86.

:x Kate Malleson provides a useful discussion of Lord Denning's judgment. See Kate Malleson, "Appeals against Convietion and the Principle of Finality" (1994) 21 J.L. \& Soc'y 151 at 159.

(1997), 33 O.R. (3d) 202 (C.A.).

lbid, at 214.

[1996] 2 S.C.R. 223.

lbid, at para. 54, citing R. v. Wigmom. [1987] I S.C.R. 246 at 257. 
of the court are strictly defined by the respective civil codes. It has been argued that the German system, with free evaluation of evidence and a professionalized judiciary, contains fewer possibilities for error, which results in an appeals system without the danger of having an inordinate number of successful claims. ${ }^{33}$ Similar arguments could probably be made regarding the operation of appeals and finality in the French criminal justice system. The point is that the notion of finality will necessarily impose limits on the scope and operation of appellate and post-appellate review, depending on the structure that leads to a "final" judgment.

Of course, finality does not literally mean final nor does it imply that court judgments are infallible. ${ }^{34}$ The import is not that the concept of finality is a cause of wrongful convictions, but rather that it provides foundational support for arguments which limit remedies for allegations of miscarriages of justice and helps create an institutional culture that is skeptical of such attempted remedies. ${ }^{35}$ In Canada, judicial finality is the reason why ministerial review is regarded as an extraordinary avenue; finality has become a conceptual restraint for the judiciary's exercise of discretion to hear collateral attacks of wrongful convictions. ${ }^{36}$ In France and Germany, post-conviction review is also extraordinary, but this may be more related to the process which leads to a final determination. Finality in Continental criminal justice systems seems to be justified by, rather than acts as a justification for, the rules of criminal procedure.

\section{Appellate and Post-Appellate Review}

\section{A. France}

There are three courts of first instance in the French criminal justice system: the Tribunal de Police (Police Court) which deals with contraventions (minor olTences); the Tribunal Corretionel (Correctional Court) which deals with delits (major offences); and the Cour d'Assises (Assize Court) which deals with crimes (grave offences). Some matters can be transferred from the Assize Court to the Correctional Court by a process called correctionalisation. There are two appeal courts in the French system: the Cour d'Appel (Court of Appeal) rehears and can substitute its judgment on questions of fact (that is, it can conduct a trial de novo, although it is not obligated to hear oral evidence and usually rules on the basis of the written record) of matters decided by the Police Court and the Correctional Court; the Cour de Cassation (Supreme Court) deals with questions of law and procedure from the Assize Court and the Court of Appeal. The Supreme Court does not consider questions of fact; successful appeals to the Supreme Court will result in the case being referred back to the Court of Appeal or the Assize Court for rehearing on the merits." 45. 
The French method of wrongful conviction review - the pourvoi en revision - is codified in the Code de procédure pénale ${ }^{38}$ It is available for a crime or a delit - that is, the conviction must be for a criminal rather than a minor or disciplinary offence. The process can be initiated by the Minister of Justice, the convicted person or his legal representative or, if he is deceased, a spouse, child, parent, relative or legatee. ${ }^{39}$ Section 622 of the $C P P$ provides four clearly defined grounds upon which this extraordinary remedy can be considered:

(1) when after a conviction for homicide, cvidence appears that indicates the supposed victim is alive;

(2) when after a conviction for a serious or major offence, another accused has been convicted of the same act and the two convictions being irreconcilable, their contradiction is proof of the innocence of one or the other of the convicled persons;

(3) when after a conviction, one of the witnesses has been prosecuted and convicted for false testimony against the accused;

(4) when after a conviction, new facts or evidence unknown at the time of the trial is produced or revealed so as to create doubt about the guilt of the accused.

The notion of "new facts" may comprise the following: the admission of a third party, the statement of a witness, the discovery of mental disorder in the convicted person at the time of the events, and new interpretation of a fact already known (for example, through technological advancement in science). ${ }^{\text {"1 }}$ The State generally does not take a proactive approach to reinvestigation; the applicant is responsible for initiating the proceedings and presenting evidence that a miscarriage of justice occurred. There is no limit to the number of times a review can be requested. ${ }^{42}$

The application is addressed to a Commission of five judges from the Supreme Court. The Commission sits as a sort of examining magistrate (like the juged 'instruction who supervises pre-trial investigations) and considers the file and application, and has the power to call for further investigation. If the Commission considers the application for pourvoi en révision well-founded, it will refer the case to the Criminal Division of the Cour de Cassation, sitting as a court of revision. The Court rehears the facts and merits of the case (it is not bound by the application or the evidence in the dossier) and decides whether to annul the conviction and award damages, or order a new trial before another court of the same rank as the one whose judgment is annulled (a new trial is not ordered and an acquittal is entered if the accused is not able to stand for trial or the evidence required to conduct a new trial is no longer available). ${ }^{43}$

Art. 144(2) C. proc. pén [CPP].

Osner, Quinn \& Crown, supra nole 20 at 90.

Canada, Department of Justice. Addressing Miscarriages of Justice: Reform Possibilities for Secrion 690 of the Criminal Code (Consultation Paper) (Otlawa: Departunent of Justice, 1998), online: Internet Archive <hltp://web.archive.org/web/20050312202552/http://canada.justice.ge.ca/en/cons/amj/ coverre. html> [Addressing Miscarriages of Jtesfice]. See also Osner, Quinn \& Crown, ibid.; Jean Pradel, "France" in Christine Van Den Wyngatr, ed., Criminal procedure systems in the European Community" (London: Butterworths, 1993) 105 at 134-35.

For an actual example of this, see Anyangwe, supra note 26 at 82.

Osner, Quinn \& Crown, supra note 20 at 90.

Jbid. at 89-90. 
As noted previously, French courts are not bound by technical or inflexible rules of evidence, according to the principle of French criminal justice that "[a]ll forms of evidence are admissible as long as they do not conflict with the ethics of the system of criminal procedure." ${ }^{\text {*4 }}$ The pourvoi en révision is necessarily for a review of the whole case and the duty of the Supreme Court, sitting as a court of revision, is "to search for the objective truth and not merely admissible evidence. In pursuit of that goal it may examine, hear or refuse to hear any witness ... [and/or] give considerable latitude to witnesses ... [and] may undertake any further investigation it thinks necessary." conviction review mechanism resembles the procedures of the original pre-trial investigation and trial process (and the appeal process in the Court of Appeal for contraventions and délits). Altematively, although it is deemed "an extraordinary remedy," the pourvoi en révision may be considered as merely introducing a mechanism to appeal from the decisions of the Assize Court and re-examine the facts and merits of the case.

\section{B. GermanY}

There are three tiers of criminal courts of first instance in Germany: ${ }^{\text {th }}$ the Amtsgericht (Local Court) has jurisdiction "in cases where a penalty not exceeding 3 years is to be expected"; the Oberlandesgericht (High Court or Higher Regional Court) deals with offences against the state and other grave offences conducted in the course of these offences; and the Landgericht (District Court or Regional Court) has jurisdiction with respect to serious offences that do not fall under the jurisdiction of either the local court or Higher Regional Court. $^{47}$

The judgment on the merits rendered by a Local Court can be appealed against - this procedure is the Berufung and essentially consists of a trial de novo by the District Court. There can be no Berufung from the trial judgments of the District Court; however, both the trial and Berufung judgments of the District Court can be appealed to the Regional Court on questions of law. Similarly, the Regional Court's trial and Berufing judgments can be appealed to the Federal High Court, the highest court in Germany, for the purposes of appealing questions of law from the decisions of Local, District, and Regional Courts. The German Code of Criminal Procedure (StPO) provides the specific grounds on which an appeal on a question of law is allowed, and includes certain procedural defects which lead to an automatic reversal of judgment. ${ }^{48}$

The StPO details the procedure for Wiederaufnahme (extraordinary appeal or petition for retrial) where a judgment cannot be appealed against any further; ${ }^{49}$ both the prosecutor and defendant can use this to apply to have the case reopened. An application for the

Pradel, supra note 40 at 118.

Anyangwe, supra note 26 at 89.

Osner, Quinn \& Crown, supra note 20 at 98.

The jurisdiction of the various courts is striclly defined by the Gerichstverfassungsgeselz (Judicature Act). Furthermore, the seriousness of the case dictates the composition of the local and district courts (i.c., the number of professional and lay judges presiding). See Hans-Heiner Kühne, "Germany" in Van Den Wyngaen, supra note 40,137 at 142.

Osner, Quinn \& Crown, supra note 20 at 100-101.

Kühne, supra note 47 at 161; Osner, Quinn \& Crown, ibid. at 102; Robbins, supra note 33 at 42. 
extraordinary appeal must be filed with a court within the same state and of the same jurisdictional level as the one which had issued the original decision. The prosecution can apply for the extraordinary appeal if an acquitted defendant subsequently confesses to the crime. The grounds for review of a final judgment on the application of a defendant are:

1. if a document used to convict the prisoner was false or falsified;

2. if a witness who testified to the disadvantage of the prisoner gave false testimony;

3. if a judge who participated in the judgment violated his official duties to the extent that a judicial criminal punishment is provided for the violation;

4. if the criminal judgment is based on a civil judgment that has been reversed; or

5. if new evidence is discovered that tends to justify the acquittal of the defendant or a lesser punishment for a less serious crime. ${ }^{50}$

A final judgment may not be reopened to provide a different punishment for the same crime or for the purpose of mitigating the punishment because of diminished responsibility of the defendant. If the court finds the defendant's application plausible on its face, it will receive evidence and hear arguments on it to determine if the original judgment should be quashed. A successful extraordinary appeal will result in an acquittal or a new trial. Like the French procedure, a defendant will be acquitted and will not have to stand for a new trial if, at the time of the granting of the extraordinary appeal, the defendant is no longer alive, or if the lack of guilt has become obvious and the public prosecutor consents to dropping the charges. ${ }^{51}$

As with the pourvoi en révision in France, the German extraordinary appeal is aimed at guarding against errors of fact-finding and is conducted in the spirit of the rules of criminal procedure at the pre-trial and trial stages such as the free evaluation of evidence and a view towards reassessing the whole case to determine whether there is a substantial question of guilt. Applications of extraordinary appeal are not infrequent; it has been estimated that approximately 150 to 350 court decisions per year are quashed on this basis. ${ }^{32}$ As such, finality in Continental criminal justice systems appears to be justified by, rather than acts as a justification for, the rules of criminal procedure. Continental criminal procedure is prepared, and in fact structured, to relegate the principle of finality to the background where there is a concern that a miscarriage of justice has occurred. ${ }^{53}$

\footnotetext{
Jbid.

Osner, Quinn \& Crown, supra nute 20 at 102.

Ibid. at 102-103.

In addition to the German extraordinary appeal, there are two other review mechanisms available to the convicted defendant. Bricfly, the first is to file a "constitutional complaint" to the Federal Constitutional Court to address violations of constitutional or procedural rights by acts of the deciding courn; the remedy for a successful application is a srial de novo. The second mechanism is to apply to the European Commission of Human Rights (and ultimately to the European Court of Human Rights); since the European Convention on Human Rights is part of German federal law, the jurisdiction of the European Court to interpret the application of the Convention in Germany has been recognized. See Kühne, supra nole 47 at 160-6I: Robbins, supra note 33 at 43-44.
} 


\section{Remedying Wrongfui, Convictions in Canada}

\section{A. ThE MINISTER'S ROLE}

Under an ideal system of administration of justice a person convicled of a crime should, perhaps, be granted an opportunity to present in a court proof of his innocence whenever such prouf becomes available and, then, to ask the court to vacate the erroneous judgment. In practice, inflexible rules of procedure may deny to a person wrongfully convicted any further acesss to the cour. Then his only means of redress is appeal to the executive. 54

As noted previously, procedural rules are deemed far less important than accurate determinations of fact in non-adversarial systems than in an adversarial system such as that existing in Canada. Chief Justice Lehman's observation above, though made in the context of American jurisprudence, highlights the distinction between post-conviction review mechanisms utilized in Europe and those utilized in Anglo-Canadian criminal procedure. Once a convicted person has exhausted the available appellate procedures, the only avenue for redress is by petition to the executive; the person cannot directly ask the Court to reopen the process. In Canada, ss. 696.1 to 696.6 of the Criminal Code ${ }^{\text {ss }}$ set out the power of the federal Minister of Justice to review a conviction under a federal law to determine whether there may have been a miscarriage of justice:

This final option of applying to the Minister of Justice for a conviction review was part of Canada's first Crimisal Code in $1892 \ldots$... [it] allowed anyone convicted of an indictable offence to apply to the Minister of Justice for the mercy of the Crown. If the Minister entertained "a doubt whether such a person ought to have been convicted," the Minister could, "after such inquiry as he thinks proper [...] direct a new trial ... belore such court as he may think proper" ... [Amendments were added in 1923] allowing the Minister of Justice to refer a case to a court of appeal ... or to seck that court's opinion on a particular question. ${ }^{36}$

The power of the Minister is, on its face, simply that of a referral: the role of the Minister is not to second-guess the decision rendered by the courts, to substitute his or her opinion of the evidence or the arguments already considered by the courts, or to decide if a convicted person is guilty or innocent. ${ }^{57}$ However, there is a precedent case that confirms the Minister can exercise his power, based on the Royal Prerogative ol Mercy, to recommend exoneration of a wrongfully convicted person without having to order a new trial or appeal. ${ }^{58}$

The current wording of s. 696.l, which sets out the condition that triggers review is "if the Minister is satisfjed that there is a reasonable basis to conclude that a miscarriage of justice

People ex rel. Prisamem v. Brophy, 287 N.Y. 132 at 139 (C.A. 1941), Lehman C.J [emphasis added]. Supra note 23.

Patricia Braiden \& Joan Brockman, "Remedying Wrongful Convictions Through $\wedge$ pplications to the Minister of Justice Under Section 690 of the Criminal Code" (1999) 17 Windsor Y.B. Acess Just. 3 at 5 .

Canada. Department of Justice, Applying for a Conviction Review: online: Department of Justice Canada <htıp://www.justice.gc.ca/cn/ps/cer/review.pdl>.

Kenneth Norman Warwick was convicted of rape and related offences in 1976. Following new evidence that he had been mistakenly identified, the Minister of Justice, the Solicitor General, and the Attomey General recommended a free pardon under s. 748(2) of the Criminal Code: see Braiden \& Brockman, supra note 56 at 20. 
likely occurred," ${ }^{39}$ whereas the 1892 version read "if the Minister [entertains] ' $a$ doubr whether such a person ought to have been convicted," and the 1953-1954 amendment provided "'if he is satisfied that in the circumstances a new trial should be directed." ${ }^{60}$ The earlier wording clearly favours the applicant more so than the previous amendment or the current version. In comparison, an earlier version of the pourvoi en révision provision in the French $C P P$ required the new evidence to "establish the innocence of the convicted person;" the current version requires only that the new evidence "raise a doubt about the guilt of the accused."'Bl Based on the wording of the Canadian provision, and the principles identified by then-Minister of Justice Allan Rock in a previous application for ministerial review, ${ }^{62}$ the onus is clearly on the applicant and the threshold to meet is quite high.

The Supreme Court of Canada further elaborated on this burden when it considered the reference question regarding the case of David Milgaard in $1992 . .^{63}$ The Court set out the different burdens of proof that would have to be met in order to trigger the different remedies the Minister may order: proof of innocence beyond a reasonable doubt would warrant a grant of a free pardon under s. 749(2) of the Criminal Code; proof of innocence on a preponderance of the evidence would warrant a reference to a court of appeal to determine whether the conviction should be quashed and a verdict of acquittal entered; new evidence relevant to the issue of guilt which, taken together with the evidence at trial, could reasonably be expected to have affected the verdict would warrant an order for a new trial. ${ }^{\text {t. }}$

Before making a decision to determine whether an applicant meets any of these burdens, the Minister of Justice has set out a process to review applications: (1) a preliminary assessment is conducted by the Department of Justice, Criminal Convictions Review Group (CCRG) to determine if the file presents new and significant evidence; (2) an investigation is undertaken by the CCRG or an outside lawyer to determine if the evidence is reliable and relevant; and (3) a report is prepared for the Minister with the information gathered in the investigation, along with a recommendation on how to proceed with the file. ${ }^{65}$ However, other sources indicate that the process is more complex and suggest that the investigation report has to make its way through the bureaucracy before it goes to the Minister: "at each of these levels, the report can be accepted, rejected or sent back for more work on the law, the evidence or the investigation." ${ }^{66}$ Many questions have been raised about the transparency and independence of the process:

The Marshall Inquiry found that the Minister was influenced by the opinion of the Chicf Justice of the Nova Scotia Court of Appeal as to which way he should proceed. In R. V. Jarvis, the Minister was intluenced by the conflicting views held in the provincial Attorney General's office. In $R$. v. Nepoose, the Minister referred the case to the Alberta Court of Appeal "with the agreement of the Attorney General of Alberta."... It is

Criminal Code, supra note 23, s. 696.1(3)(a).

Braiden \& Brockman. stupra note 56 at 5 [emplasis added].

Addressing Miscarriages of Justice, supra note 40 [emphasis added].

lbid. at 3-4.

Reference re Milgaard, [1992] I S.C.R. 866 [Milgaard Reference].

lhid. at 869-7I [emphasis added].

Department of Justice, supra note 57.

Braiden \& Brockman, supra note 56 at 8-9 [footnoles omitted]. 
impossible to determine whose opinion and what facts the Minister of Justice will take into account in making [his] decision. ${ }^{67}$

Moreover, there is an inherent institutional conflict in that the process is managed by the Department of Justice, which also carries out the prosecution function of the Altorney General/Minister of Justice. Although the CCRG, which operates under the Policy Sector rather than the Litigation Sector of the Department, had been created to address this concern. the optics still leave much to be desired; there has been ongoing debate on whether the creation of a tribunal independent of the Minister/Attorney General and the Department with an increased degree of transparency, accessibility, and public expense is desirable or necessary. ${ }^{68}$

\section{B. THE ROLE OF THE COURTS}

Section 696 creates three intermediate steps which may be taken by the Minister of Justice: (1) the case can be relurned to a trial court for retrial; (2) it can be returned to the court of appeal for reconsideration "as if it were an appeal"; or (3) specific issues can be referred to the court of appeal for an opinion on a specific question. Clearly. "[t]he differences between the three alternatives are significant. A retrial ... would resurrect the presumption of innocence and require the Crown to prove its case afresh. A reference limits ... the appellate court to its ordinary powers and requires the convicted person to carry the burden of persuading the appellate court." ${ }^{.69}$ A reference to the court of appeal leaves the applicant with the burden of preparing and presenting the case to prove his innocence, in what is very much an adversarial setting. ${ }^{70}$ The powers of a court of appeal hearing an ordinary appeal under s. 686 of the Criminal Code apply to an appeal under s. 696. The case will be heard as if it were an appeal and thus turns very much on the question of whether the court will consider the new evidence that is being presented.

Unlike the Continental courts, Canadian courts remain bound by statutory and common law rules of evidence even when considering an appeal from a s. 696 reference. The courts in France and Germany will consider all of the evidence freely and hear the case as a trial de novo. In contrast, in Canada new evidence" must meet the test of admissibility as "fresh evidence on appeal" set out in Palmer $v$. The Queen ${ }^{72}$ to be considered - that is:

1. The evidence should generally not be admitted if, by due diligence, it could have been adduced at trial provided that this general principle will not be applied as strictly in a criminal case as in eivil cases

lbid. [footnotes omilted].

The Honourable Mr. Justice Peter H. Howden, "Judging Lirrors of Judgment: Accountability, Independence\& Vulnerability in a Post-Appellate Conviction Review Process"(2002) 21 Windsor Y.13. Access Just. 569 at 586.

Allan Manson, "Answering Claims of Injustice" (1992) 12 C.R. (4th) 305 at 314-16.

Braiden \& Brockman, supro note 56 it 10.

For the purposes of the Minister's review, information will be considered "new" il the courts did not examine it during the trial or apptal or if the applicant became aware of it after all court proceedings were over: see Department of Justice, supro note 57 at 2.

[1980] I S.C.R. 759 [Polmer]. 
2. The evidence must be relevant in the sense that it bears upon a decisive or potentially decisive issue in the trial[;]

3. The cvidence must be credible in the sense that it is reasonably capable of beliefl;) and

4. It must be such that if believed it could reasonably, when taken with the other evidence adduced at trial, be expected to have affecied the [trial]. ${ }^{73}$

The limitations established by the Palmer criteria are readily apparent:

A strategic trial choice to leave out an issue or a witness will generally preclude adducing that evidence on appeal. Secondly, even though the appellate court will not likely hear the new evidence viva voce, it will make assessments of credibility. Thirdly, the court must predict the impact the new evidence would have made on the verdict. This is an inherently speculative exercise, especially if the new evidence does not determine the issue of responsibility. ${ }^{74}$

Recognizing these issues, the Alberta Court of Appeal held in R. v. Nepoose $e^{75}$ that evidence on a reference under s. 690 (as it then was) could be admitted even if it did not strictly meet the Palmer requirements because of the "real possibility of injustice or the appearance of injustice."”

Nevertheless, the Palmer test was applied by the Ontario Court of Appeal in Reference re Kelly, ${ }^{77}$ in response to a question referred to the Court by the Minister of Justice in 1996. Justice Finlayson (Osbome J.A. concurring) wrote: "[O]ur function ... is to assess the alleged recantations and determine if the recantations meet the tests of relevance, credibility and materiality such as to warrant their reception as fresh evidence." ${ }^{78}$ The Court held that the recantations would not be admissible because they could not be considered credible since there was no explanation given as to why the witness changed her testimony and the "extraordinary" length of time covered by the recantation process. The Minister subsequently dismissed the application for review.

In the Reference Re Breese (A.R.), ${ }^{79}$ the Manitoba Court of Appeal was asked to decide the question of admissibility and, based on its opinion on that question, decide the case as if it were an appeal. The Court held that "the standard to be applied in this case is a relaxed and flexible one because it is in the interests of justice to be so" but the evidence must still meet the threshold requirement of legal admissibility ${ }^{80}$ One of the issues the Court had to consider with respect to the admissibility of certain photographs and reports, was whether the "due diligence" aspect of the test in Palmer should be applied strictly in a reference case under s. 690 of the Criminal Code. The Court was prepared to relax the Palmer standard, but held that the evidence in question was not "fresh evidence" because its subject matter was

Ibid. al 775.

Manson, supra note 69 at 314.

(1992), 125 A.R. 28 (C.A.) [Nepoose].

Ibid. al 31.

(1999). 135 C.C.C. (3d) 449 (Ont. C.A.) [Kelly Reference].

Ibid. at para. 45, citing Palmer, supra note 72.

(1998), 131 Man. R. (2d) 161 (C.A.), affd Reference re Grenke, [2000] I S.C.R. 836 [Breese Reference].

lbid. at para. 40. 
already raised at the trial. ${ }^{81}$ As for the Commissioner's report which had originally recommended the reference, the Court held that this was not admissible because the very information on which the report was based was itself not admissible: "[W]e must come to our own opinions respecting the admissibility of the 'information' before [the Commissioner], which does not ... include [her] own thoughts and conclusions." ${ }^{\text {"k2 }}$ The Supreme Court of Canada affirmed the decision in the Breese Reference and, in doing so, essentially reaffirmed the doctrine set out in $R . v$. $O^{\prime} B r i e n,{ }^{83}$ that any evidence sought to be adduced on a ministerial reference be admissible under the rules of evidence. ${ }^{8-1}$

The question of the appropriateness of appellate courts hearing references on alleged wrongful convictions was raised in the findings of the Royal Commission on the Donald Marshall, Jr., Prosecution. The thrust of the Court of Appeal's "gratuitous comments in the final pages of its decision" is to pin the blame on Marshall for his conviction and to ignore any evidence which would suggest fault on the part of the criminal justice system. Ultimately, the "Court's decision amounted to a defence of the system at Marshall's expense, notwithstanding overwhelming evidence to the contrary." ${ }^{25}$ In addition, the Court of Appeal severely chastised the Crown attorney for not taking an adversarial position (the lawyer was of the view that there was a miscarriage of justice in the case) ${ }^{86}$ Although it is difficult to mount empirical evidence that this remains a prevailing attitude in the Canadian criminal justice system and among the judiciary, it is a cause for concern when we consider the effects of such an approach to wrongful conviction review. The courts' rhetoric and practice show a long and consistent history of resistance to the very idea of a criminal appeal process, or to any expansion of it, and to the notion of wrongful conviction review. Taken together with the principle of finality, it is perhaps not surprising, but certainly disappointing, that appellate courts (and perhaps even the Department of Justice) seem to take a restrictive approach to these issues. ${ }^{87}$

\section{IMPROVING WRONGFUL CONVICTION REVIEW - Lessons of Comparative Criminal Procedure}

There seems to be much that we can learn from comparing the Canadian wrongful conviction review process to those found in Continental criminal justice systems. However, any comparisons or suggestions for change to our system must be prefaced with some caveats. It is, of course, impossible to recommend wholesale adoption of either the French or German method (or a hybrid of the two) given the inherently different nature of our respective systems. As noted previously, the distinct theoretical and practical differences between criminal procedure in Canada, France, and Germany will necessarily limit the type of review mechanism that may be adopted within these systems. Furthermore, since there is no available reliable statistical evidence on the phenomenon of wrongful convictions or post-

\footnotetext{
si Ibid. at para. 73.

* Sbid. at para. 83.

11 [1978] I S.C.R. 591.

Hat at 602 .

45 Nova Scotia, Royal Commission on the Donald Marshall, Jr., Prosecution, Commissioner's Report Findings and Recommendations, vol. I (Halifax: McCurdy's Printing and Typesetting. 1989) at 116.

Ho Boid. all 84.

"7 Braiden \& Brockman, supra note 56 at 21.
} 
conviction review in Europe, it would be unfair to conclude simply from the comparison of the basic structures that adopting the foreign approach in Canada would lead to fewer cases of miscarriages of justice or that applications for review would be treated more fairly or expeditiously. No system of review can be perfect; indeed, the very fact of the existence of wrongful convictions demonstrates that any human system will be inherently fallible. Nevertheless, it may be worthwhile to consider some aspects of the French and German approaches.

\section{A. Vetting a. APpi.ICATION}

The ultimate decision to grant a remedy is very much a function of the initial decision on whether a review will be conducted. The present process of review by the Department of Justice (or a non-governmental third party designated by the Minister) has been criticized by academic writers, interested parties, and applicants' representatives: the Department is viewed by many of the process stakeholders as suffering from a prosecutorial bias and the Minister/Attorney General is seen as being in a position of conflict between the role as defender of the legal and constitutional slatus quo and arbiter of the fate of claimants alleging systemic error. ${ }^{88}$ Braiden and Brockman have noted that some Department of Justice officials who review ministerial review applications approach such investigations with more than a healthy dose of skepticism, which may lead to an undue deference to judicial determinations of guilt and an insufficiently rigorous questioning of the foundations of criminal convictions. ${ }^{39}$ The debate on this issue has long focused on the need to establish an independent body to investigate allegations of miscarriages of justice, along the lines of the commissions in England and Scotland."

In contrast is the French and German approach, which assigns the functions of initial review and ultimate decision to the courts; the Commission of the Supreme Court in France, and the court of equal jurisdiction in Germany. ${ }^{91}$ However, similar concerns about institutional bias and conflict arises: since the review committee is composed of professional judges, they may be biased towards approaching cases from a strictly legal point of view and be inclined to protect the finality of the trial process. There are other institutional concerns, namely the resources and time that would need to be allocated for judicial investigations.

On the other hand, there is an intangible benefit to having the courts (or judges) themselves responsible for vetting the applications for review: there would be a stamp of legitimacy (albeit unofficial) that accompanies a case that has been inspected by judges and that has been recommended for further review. The Nepoose case is illustrative on this point:

[T]he court took the unusual step of appointing a special commissioner under s. 683(1)(e)(ii) to hear and consider new evidence. Thus, the court's schedule was not eaten away by the exigencies of the case. Mone importantly, the commissioner's 253-page report included his assessment of the impact of new evidence on

* In the U.K., see the Criminal Cases Review Commission (CCRC), online: CCRC <hitp://www.cere. gov.u.k./index.htm>; in Scotland sec the Scottish Criminal Cases Review Commission (SCCRC), online: SCCRC <http://www.secre.org.uk/home.aspx>. 
the verdict from the perspective of the trial dynamic. As a result, the Court of Appeal could appreciate the functional effect of the diminution of the recanting witness's lestimony even though the commissioner concluded that not all of her trial evidence could be "discounted as false. ${ }^{92}$

What is proposed then is a hybrid of the two models - the independent commission model and the judicial vetting model - which, as demonstrated by the Nepoose case, is already within the powers of the court under $\mathbf{s}$. 683 of the Criminal Code. The vetting and investigation of applications should be assigned to a commissioner named by the court of appeal, who will provide a non-binding recommendation to a panel of appellate judges. The panel would then make the ultimate decision on whether the case should be adopled for review. Commissioners would be selected randomly from a pool of retired judges, academics, or criminal lawyers, a mechanism which would provide the institutional independence required to instill public confidence in the system of review.

Overcoming the initial hurdle of the vetting process is perhaps the biggest obstacle faced by persons claiming a miscarriage of justice. This proposed mechanism would go a long way towards circumventing the institutional barriers that have been identified by various scholars. It promotes the integrity and independence of the vetting process, while working with the institutional reality and the organizational psychology of the actors in the system.

\section{B. Avallabi.f. Rfmedies}

The power of ministerial review was traditionally contemplated as an extension of the Royal Prerogative of Mercy. ${ }^{93}$ In fact, however, this is misleading: there is nothing about the notion of the discretion to grant a pardon that requires it to be predicated on a court decision. Therefore, there must first be a distinction made between the power to pardon and the remedies of ordering a retrial or a new appeal. They do not have to be coupled together: the Minister can quash a wrongful conviction without ordering a retrial or a new appeal. The

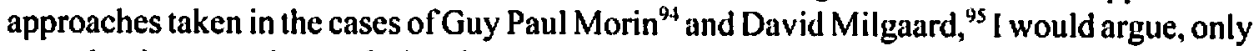
served to increase the confusion for advocates about what remedy should be requested on a petition for review.9 It should also be noted at this point that persons applying under the $s$. 696 process often do so with little or no assistance from qualified legal professionals. ${ }^{97}$

The simplified vetting process advocated in the foregoing may help address this concern: the court-appointed commissioner can make a recommendation to the court of appeal to recommend the grant of a pardon by the Minister in cases where the innocence of the

$92 \quad$ Manson, supra note 69 at 318.

91 Braiden \& Brockman, supra note 56 at 5-6.

o4 Milgaurd inquiry, stapra note 5 .

4. Milgcard Referestoce, supra note 63.

- David Milgaurd has never been formally acquitled, although by ordering a new trial, the Minister effectively quashed the conviction; the Saskatchewan Attorney Gencral stayed the eharges and declined to conduct a new trial. Guy Paul Morin's convietion was overnumed by the Ontario Court of Appeal and an acquittal was entered.

v? The Association in Defence of the Wrongly Convicted. supra note 2, and the Osgoode Hall Law School Innocence Project (online: <htt://ww w. innocenceproject.cas) and its associated network of legal clinics offer pro bono legal advice and will, to some extent, undertake some investigations to assist applicants. 
applicant is clearly established, ${ }^{98}$ "thereby obviating the need for a reference back to court. If the Minister ... chooses not to act on this recommendation, the case must be referred back [for retrial or a new appeal]. It would not be acceptable that the inquiry produces a conclusion in favour of the convicted person but that Ministerial intervention removes the prospect of any relief." 99 In all other cases meeting the criterion for reference (discussed below), the remedy would be either a retrial or a new appeal. Again, this would be the subject of a commissioner's recommendation, with the ultimate decision being rendered by the court of appeal.

\section{Determining When a Remedy is JUSTIFIEd}

The guidelines fashioned by the Supreme Court of Canada in the reference case of David Milgaard, though helpful in distinguishing between the requirements for a retrial or new appeal, set a considerably high (and complicated) threshold for post-conviction review applicants. However, this is somewhat more favourable in that nowhere does the Court require a test that a miscarriage of justice "likely" occurred, in contrast to the wording of s. 696.1(3)(a) of the Criminal Code. ${ }^{100}$ Nevertheless, as noted above, there are practical difficulties for applicants who are not legally trained or may not have access to legal assistance and thus may not be able to decipher the meaning of a "preponderance of the evidence" or determine whether the new evidence "could reasonably be expected to have affected the verdict." 101

Thus, there should be a distinction between the standard to be met by the applicant and the standard used by the court of appeal in rendering its decision. To simplify the process, the criterion for review, from the applicant's perspective, should be "lurking doubt" or, in the terms of the French provision, "new evidence creat[ing] doubt about the guilt of the accused." 102 It would then be up to the court-appointed commissioner to: (1) make a recommendation of whether "lurking doubt" does in fact exist, on the basis of the new evidence considered with the evidence at trial; and (2) to determine, by way of his or her legal training, whether that lurking doubt could (a) reasonably be expected to have affected the verdict, or (b) to increase the preponderance of the evidence in favour of the applicant. The simple policy reason for adopting this standard is to allow the applicant to take refuge in the presumption of innocence: there should be no reason why, especially in light of new evidence, the applicant should have to overcome a presumption of guilt that has been tainted by the existence of a lurking doubt.

\section{RECEIVING "Fresi" EVIDENCE}

Clearly, these prescriptions for a simplified process would be for naught if, at the hearing of a new appeal, the new evidence were ruled inadmissible according to the restrictive test in

I prefer to relruin here from using "loaded" legal terms like "beyond a reasonable doubt" or "plain and obvious." I would, however, recummend adopting the French and German use of "substantive pros)l" or intime conviction.

Manson, supra note 69 at 323.

100 See supra note 59 and accompanying text.

101 Milgaard Reference, supra note 63 at 871.

102 Osner, Quinn \& Crown, supra note 20 at 90; Addressing Miscarriuges of Justice, supra note 40. 
Palmer. ${ }^{103}$ The Breese Reference ${ }^{104}$ and Kelly Reference ${ }^{105}$ discussed above illustrate how the Canadian appellate courts have allowed themselves "to be a slave to technical and often inflexible rules of evidence even when sitting on a [ministerial] reference." 106 The simplest way to overcome this would be the enactment of legislation distinguishing (and relaxing) the criteria for admissibility of "fresh" evidence on an application for post-conviction review from that of a regular appeal. Specifically, the Palmer requirement of "due diligence" should be abrogated because of the important policy consideration at stake: the "real possibility of injustice or the appearance of injustice." 107 In addition, to prevent the recurrence of the situation in the Breese Reference - where the Manitoba Coun of Appeal ruled inadmissible the commissioner's report to the Minister which recommended the rehearing - it should be made explicit that the recommendations of the court-appointed commissioner in the prescribed scheme are prima facie admissible.

Considered alternatively, the procedure for receiving evidence on a post-conviction review should more closely mirror the inquisitorial or non-adversarial process. Once an application has been "certified" by the court-appointed commissioner as warranting review, the court of appeal should take an active interest in ensuring that a miscarriage of justice is not perpetuated. The French and German systems highlight the possibilities for a robust and thorough wrongful conviction review process - the key element is the commitment to substantive justice, a commitment in which common law judges would claim no less interest.

\section{Conclusion: The Plea for Utilizing Foreign EXPERIEnce}

"Ever since Solon of Athens traveled to the other Greek city-states and studied their laws in order to benefit from their experience while he was drafting laws for his own people, comparative studies have been undertaken for the pragmatic purpose of gaining perspective in critically appraising one's own domestic law." ${ }^{\text {ok }}$ Not only have I attempted in this article to survey Continental criminal procedure in order to critique and appraise the Canadian approach to wrongful conviction review, I have also aimed to harness that foreign perspective to inform my recommendations for improvement to that process. I have argued that incorporating specific elements of European practice into our domestic procedures would substantially increase and improve the opportunities for correcting miscarriages of justice in Canada.

The problem of wrongful convictions is serious and thus warrants scholarly and public attention, but it also requires practical solutions to provide actual remedies to the very real people who are affected by this issue. Post-conviction review is not just a "safety valve" for the criminal justice system; it is the only hope of the wrongfully convicted. Clearly, there must be ongoing study and public education about the systemic causes of wrongful conviction, as has been carried on by various scholars and interest groups: an ounce of 
prevention, as they say, is worth a pound of curc. But for the hundreds (and perhaps thousands) of people who languish in our penal system for crimes they did not commit, the most important help they can receive is having access to a fair, efficient, and open review process on the way to formal exoneration. 